\title{
FLIGHT TO CANADA AND KINDRED: SIMILARITIES AND DISCREPANCIES IN TWO NEO-SLAVE NARRATIVES TRANSLATED INTO SPANISH
}

\author{
VUELO A CANADÁ Y PARENTESCO: SIMILITUDES Y DISCREPANCIAS \\ EN DOS NOVELAS DE ESCLAVITUD TRADUCIDAS AL ESPAÑOL
}

\author{
Miguel Sanz Jiménez \\ Universidad Complutense de Madrid \\ miguelsanz@ucm.es
}

\begin{abstract}
The aim of this paper is to study the Spanish translations of Ishmael Reed's Flight to Canada and Octavia E. Butler's Kindred, two neo-slave narratives that were published in the 1970s. It examines how Black English, the lexicon of slavery, and proper nouns have been recreated in the Spanish target texts. The linguistic variety spoken by the secondary characters in Flight to Canada and by the slaves in Kindred makes readers aware of the language of the dispossessed Other. Butler's and Reed's novels were published simultaneously in Spain in 2018 and translated by Amelia Pérez de Villar and Inga Pellisa, respectively. This paper observes how translators' choices play a key role in the portrayal of alterity in literary texts.
\end{abstract}

Keywords: African-American Literature; Black English; Ishmael Reed; Octavia E. Butler; Literary Translation; Slave Narratives.

\section{Resumen}

Este artículo estudia Vuelo a Canadá y Parentesco, las traducciones españolas de las correspondientes obras de Ishmael Reed y Octavia E. Butler, dos novelas de esclavitud que se publicaron en los años setenta. Se examina cómo los textos meta españoles recrean el inglés afroamericano, el léxico de la esclavitud y los nombres propios. La variedad linguiística utilizada por los personajes secundarios de Vuelo a Canadá y los esclavos de Parentesco acerca a los lectores al lenguaje del otro desposeído. Las novelas de Butler y Reed se publicaron simultáneamente en España en 2018 y sus traductoras son Amelia Pérez de Villar e Inga Pellisa, respectivamente. Este trabajo analiza cómo las decisiones de las traductoras juegan un papel crucial en la representación de la alteridad en los textos literarios.

Palabras clave: Literatura afroamericana; inglés afroamericano; Ishmael Reed; Octavia E. Butler, traducción literaria; novelas de esclavitud. 


\section{Introduction}

Ishmael Reed's Flight to Canada and Octavia E. Butler's Kindred are two subversive novels published in the late 1970s that play with language, AfricanAmerican history, and ideas of race. They belong to the subgenre of neo-slave narratives and, despite their critical success in their source context, they were not translated into Spanish until 2018 - four decades after their original release.

This paper observes how Black English is portrayed in Reed's and Butler's novels. In them, this linguistic variety is part of the slaves' identities, who are seen as the dispossessed Other by their white oppressors. The study of the renderings by Pellisa and Pérez de Villar-the respective translators of Flight to Canada and Kindred - examines the strategies chosen to recreate literary dialect. Therefore, the analysis of these two target texts will show if the alterity introduced by the source novels is reflected or suppressed from the Spanish versions. For this purpose, the notion of 'narrative' will be taken into account, which Baker defines as "the everyday stories we live by... that change in subtle or radical ways as people experience and become exposed to new stories" (3), meaning the stories that people tell themselves about their history and place in the world to make sense of their lives, a key concept for studying African-American slave narratives.

Furthermore, this paper looks into the strategies chosen by Pellisa and Pérez de Villar in order to cope with the lexicon of slavery, particularly those terms alluding to skin color and Southern plantations. This is followed by looking closely at the translation of the slaves' meaningful names, which may shed some light on the underlying publishing policies that influence the reception of AfricanAmerican slave narratives by Spanish readers.

\section{African-American Neo-Slave Narratives}

By the end of the eighteenth century, the first African-American slave narratives were published, combining diverse genres from which they inherited certain storytelling techniques, namely "spiritual autobiographies, conversion narratives, sea adventure stories, and picaresque novels" (Gould 12). The rise of abolitionism in the 1830 s and 1840 s favored the publication of first-person accounts written by former slaves, such as Frederick Douglass, to disclose the horrors that were taking place in Southern plantations. These autobiographies chronicled slaves' routines, the abuses they suffered, their search for identity, and acts of resistance. As Gould argues, "many of the narrative and thematic conventions which were apparent yet not fully developed in eighteenth-century works take shape in this period" (19), for instance, the portrayal of sadistic Southern masters, brutal scenes of whipping, and stories of slaves who rebel and run away to the North. It needs to be pointed out, though, that slave narratives did not recreate Black English in the printed 
page, a strategy aimed at showing that blacks could also speak Standard American English and write according to its norms (Depardieu 123-24).

In the 1960s, and partly as a consequence of the Civil Rights Movement and Black Power, African-American slave narratives evolved into a literary subgenre that explores the peculiar institution under post-modern perspectives. These novels are known as neo-slave narratives, a denomination coined by Bell, who defines them as "modern narratives of escape from bondage to freedom" (289). Rushdy has studied them in detail and states they are "contemporary novels that assume the form, adopt the conventions, and take on the first-person voice of the antebellum slave narrative" (3). This scholar argues that the social changes of the sixties contributed to the emergence of neo-slave narratives in the following decades, since certain connections could be made between the antebellum United States and the unrest in the 1960s, as in this decade "race occupied the center stage of American politics in a manner unprecedented since the Civil War" (7). In the aftermath of the Civil Rights Movement, "slavery erupted onto the national scene as a matter of intense public interest and debate" (Dubey 333). Black writers dealt with issues of contemporary racial identities by adopting the voices of fugitive slaves and reconstructing slave narratives, that is, the early texts articulating African-American subjectivity.

The first novel to be published that belongs to this subgenre is Margaret Walker's Jubilee (1966), which retells her great-grandmother's experiences of life in bondage and underlines the importance of the "black oral tradition" (Dubey 334). In contrast to previous canonical texts that relegated black slaves to the background-for instance, Margaret Mitchell's Gone with the Wind, whose film adaptation is still controversial in 2020 - neo-slave narratives retell historical events from the slaves' point of view and disclose a hidden side of the United States' traumatic past. These novels play with different genres, introduce formal innovations, and deal with the institution of slavery from diverse perspectives; for example, they resort to humor and anachronism to emphasize the absurdity of this institution and Southern masters, as in Ishmael Reed's Flight to Canada (1976). These novels can add elements from science-fiction, too, such as time-travel in Octavia E. Butler's Kindred (1979).

Since their emergence in the 1960s, neo-slave narratives have turned into "an extraordinary genre of retrospective literature about slavery that exploded in the last decades of the twentieth century and shows no signs of abating" (Smith 168). They are still being published in the early twenty-first century, when novels about life in bondage can help explore contemporary issues of racial identities. This is the case of Colson Whitehead's multi-awarded The Underground Railroad (2016), in which the clandestine network that helps slaves escape to the North becomes an actual subway running across the country. It was translated into 
Spanish in fall 2017. The success of Whitehead's novel may have triggered interest in neo-slave narratives and could have contributed to the translation of Reed's and Butler's works, since these two books under study were published in Spain for the first time just a few months later, in spring 2018.

\section{Translating Neo-Slave Narratives}

\subsection{Black English}

In contrast with the nineteenth-century autobiographies mentioned above, neoslave narratives do often portray Black English on the printed page and allow the protagonists to speak their own linguistic variety. This poses an extra challenge to the translators of Flight to Canada and Kindred, so this subsection identifies some of the key features of this literary dialect, as well as a series of strategies to translate it.

Also known as African-American Vernacular English, ${ }^{1}$ Black English is "the whole range of language varieties used by black people in the United States ... both in cities and in rural areas, and by all age groups of both sexes" (Mufwene 291-92). In works of fiction, it is usually depicted through the eye-dialect technique, which consists of indicating "on the printed page, through spellings and misspellings, elisions, apostrophes, syntactical shifts, signals, etc. the speech of an ethnic, regional or racial group" (Zanger 40). In other words, writers may play with spelling in an attempt to reflect non-standard pronunciations and mark the lines of certain characters, often seen as the Other.

The features of Black English present in neo-slave narratives may be classified in two main categories: morpho-syntactic and phonological traits. Nine of them will be described in the following paragraphs - seven are morphosyntactic and the other two fall under the phonological umbrella. The eye-dialect technique serves to portray the following two phonological traits: the pronunciation of the ending $/ \mathrm{y} /$ as $/ \mathrm{n} /$ in verb gerunds (Green 121) and the suppression of unstressed initial syllables (Minnick 66). The last two features ${ }^{2}$ can be appreciated in the next fragment, taken from Flight to Canada. A slave named Uncle Robin bumps into Cato, a mulatto also in bondage, and does not pronounce the first unstressed syllable in 'refreshments'. Cato corrects him, yet his intervention is marked by another phonological trait of Black English — changing $/ \mathrm{y} /$ for $/ \mathrm{n} /$ in verb gerunds when he says "goin".

\footnotetext{
${ }^{1}$ This paper will alternate between Black English and African-American Vernacular English to refer to the linguistic variety under discussion, indistinctively.

${ }^{2}$ The features of Black English being discussed have been highlighted in italics in this paper. This happens in the following examples as well, unless otherwise stated.
} 
"I'm sorry, Mister Cato, but I thought maybe you and Massa Swille would like some 'freshments."

“'Freshments, 'freshments. When are you going to learn? Refreshments. How are we goin to gain acceptance if we don't show that we know Dr. Johnson and them." (Reed 54)

Regarding morpho-syntactic features, translators need to take into account "invariant be" (Rickford and Rickford 113), which is the use of the verbal marker 'be' to make predictions; the omission of the third-person singular $-s$ in the present tense (Rickford and Rickford 110-14); the zero copula, that is, the suppression of the verb to be between a subject and its attribute (Mufwene 299; Rickford and Rickford 114); and the omission of auxiliary verbs in compound forms such as present perfect and continuous (Green 166). The following fragment, taken from Flight to Canada, may illustrate the morpho-syntactic features of AfricanAmerican English just enumerated. In it, Arthurs Swille, the plantation's owner, is woken up by Mammy Barracuda, who tells him Ms. Swille is doing odd things for a Southern belle. When describing her mistress's habits, Barracuda uses invariant be, omits the third-person singular $-s$ in the present tense, and drops auxiliary verbs and verb copulas.

"Barracuda, what on earth's the matter? I'm having my 'Siesta.' I ..."

“Your 'Siesta' gon have to wait. It's your wife again, Arthur. She looks real Emancipated. Dark circles under the eyes. Peek'd. She say she not going to talk unless she fed intravenous. She say she on strike. All she do now is lay in bed, watch television, read movie books and eat candy. She drinks an awful lot, too, Mr. Swille. She be listening to that Beecher Hour show." (Reed 110)

Furthermore, the neo-slave narratives under study display other three morphosyntactic features of Black English, which are the preference of the demonstrative 'them' as a substitute of the standard 'those' (Rickford and Rickford 110-14), as in "I'm sick of seeing you in them pants" (Butler 165); double negation with the contraction 'ain't' as the negative particle (Green 76), like "People think she ain't got no good sense" (Butler 76); and, lastly, marked questions, meaning there are no auxiliary verbs in the initial position and there is no inversion between the subject and this verb (Green 84; Rickford and Rickford 124), as can be appreciated in "You think he'll come back for you, Dana, you ... husband?" (Butler 151).

Viewing the portrayal of the morpho-syntactic and phonological features of Black English in the neo-slave narratives under study, what can translators do when facing such a hurdle? Rica Peromingo and Braga Riera (133-34) comment that it is translators' task to study the function of dialect in the source and target 
texts. They offer six strategies for translating literary dialect (134-43): dialect compilation, which mixes idioms and colloquial expressions from the target language while maintaining the original setting; pseudodialectal translation, consisting of resorting to substandard target language registers to recreate a fictional non-regional variety; parallel dialect translation, or selecting a given geographical dialect from the target language with similar connotations to the one in the source text; dialect localization, which transports dialect, cultural references, and the setting to the target culture; standardization, which consists of translating everything into the normative target language and suppressing any sign of linguistic variation in favor of readability; and, last of all, compensation, or rendering a few instances of dialect into standard language and marking other fragments in the target text to balance this loss.

\subsection{The Lexicon of Slavery}

Neo-slave narratives share certain lexical terms - pertaining to skin color and the plantation world - that are interesting to observe in the Spanish versions to check if there are similarities in the way they have been rendered or, on the contrary, there are some discrepancies between translators.

In the semantic field of skin color, neo-slave narratives use the offensive word 'nigger' to generally refer to black slaves, together with the variants 'Negro', 'dark', and 'colored'. The translation of 'nigger' may be very troublesome, since this word evokes "one of the richest, nastiest, and most complex ranges of meaning in the English language ... the slur refers to someone inferior, even exploitable" (McWhorter n.p.). Besides, there are several adjectives that specify the degree of blackness a slave can have, like 'quadroon', referring to a slave who has one fourth of African blood but is still "recognized as being black by the law and custom of the antebellum South" (Rodriguez 431); and 'high-yellow' and its eye-dialect variant 'high-yaller', which are applied to slaves who have a very light skin color, usually as a result of miscegenation. Another offensive adjective that comes up in neo-slave narratives is 'pickaninny', a term that may stem from the Portuguese pequenino and alludes pejoratively to black children in the South.

The second semantic field to be taken into account involves the plantation world and the roles black and white characters play in it. For instance, there are a series of nouns that denote the jobs white people have, such as the 'master' who owns the plantation and slaves - with its eye-dialect variants 'massa' and 'marse' - and the 'overseer' who supervises field slaves and whips them in 
punishment. In Kindred there are also "slave patrols'3 watching over the plantations and doing most of their work "at night on roads, in fields, and between the farms of their neighbors, making sure that slaves went where their masters intended them to go" (Rodriguez 410). They had 'bloodhounds', that is, dogs that were trained to sniff fugitive's trails, chase and even maul them in order to return runaways to their white masters. Moreover, the semantic field of the plantation world contains references to slaves' traditions, like jumping over a broomstick in a marriage ceremony to celebrate the union of the bride and the groom. It may be revealing to observe if these cultural references have been preserved, omitted, or explained in a footnote in Vuelo a Canadá and Parentesco and to contrast translators' strategies.

\subsection{Proper Names}

Before moving on to the analysis of the target texts, it needs to be considered that, in neo-slave narratives, proper nouns can be highly revealing, as they can "be used as characterizing devices in literary texts and so become a meaningful element in the texture of such works" (Manini 161), carrying and additional semantic load that may include puns and wordplay. Even though people's names are often arbitrary and their function is simply to distinguish particular people, in fiction they can convey connotations and describe traits of the person to whom they refer. Manini calls them loaded or meaningful names, in contrast with conventional names that identify a character (162). Meaningful or loaded names characterize someone in fiction, resort to wordplay, and work as "comment of the character's personality" (163). When it comes to the strategies for translating meaningful names, they can be left untranslated and unexplained in the target text, they may be reproduced with the addition of a footnote explaining their connotations, or these loaded names may be transcribed, that is, "translated or adapted on the level of spelling" (Manini 167).

In the two novels under study, some black slaves have loaded namesespecially in Flight to Canada, with characters like Mammy Barracuda, Raven Quickskill, Uncle Robin, and Leechfield. Therefore, the study of proper nouns and their corresponding Spanish versions will be part of the analysis of translated neoslave narratives.

\footnotetext{
${ }^{3}$ These groups of armed white men that attacked slaves may have influenced the violent methods of the Ku Klux Klan when the Civil War was over.
} 


\section{Flight to Canada, by Ishmael Reed}

Reed's novel begins with a poem, also titled Flight to Canada, written by Raven Quickskill, a slave who runs away from Arthur Swille's Camelot plantation with his friends, 40s and Leechfield. Swille gets ready for the Civil War and invites a series of celebrities to his plantation, including President Lincoln, Jefferson Davis, and Queen Victoria. He is helped by his faithful slaves, Uncle Robin and Mammy Barracuda. She fights with Ms. Swille, who has decided to become a feminist and refuses to put up with the duties of a Southern belle. Raven makes it to Canada, realizes that black people are free but segregated, and returns to Virginia. Arthur Swille is murdered, the slaves are freed at the end of the Civil War, and Uncle Robin inherits Camelot.

Ishmael Reed's satire came out in 1976, the same year as Alex Haley's Roots and coinciding with the United States' Bicentennial. Although it was eclipsed by the overwhelming success of Haley's family saga, reviewers noticed that Flight to Canada is "a demonized Uncle Tom's Cabin, a book that reinvents the particulars of slavery in America with a comic rage" (Charyn n.p.), because the novel blends conventions taken from nineteenth-century slave narratives and minstrel shows to explore a postmodern setting that combines past and present. Flight to Canada parodies other books of historical writing — such as Styron's The Confessions of Nat Turner - and questions their construction of truth regarding slavery, that is, Reed's short satire serves "to expose the unreliability of the official historical record of slavery" (Dubey 339). Additionally, the use of anachronisms and intertextuality allows this novel to reflect on how slaves' longing for freedom is still present in the oppression endured by black citizens in the 1970s. With a swift plot alternating between Raven's journey to the North and the misfortunes taking place at the Camelot plantation, Flight to Canada plays with time and history to ponder how little the situation may have changed in the aftermath of the Civil Rights Movement because, as O'Neale explains, “the black man's condition has never changed. Whether in 1855 or 1975, the black man still longs for a nonexistent flight to Canada in quest of a freedom unobtainable at home" (175). By introducing contemporary elements such as planes, Greyhound buses, telephones, and TV, Flight to Canada links the 1850s to the civil unrest of the 1960s and the early 1970s. What is more, the novel subverts the idyllic South portrayed in Mitchell's Gone with the Wind and depicts it as the home of a medieval culture with a slave plantation named after King Arthur's castle. In it, slaves are tortured, women lock themselves away in their rooms, and Arthur Swille's business ethics are contrasted with his refined aristocratic manners.

Despite its positive reviews and contribution to African-American fiction, Reed's satire had to wait over forty years to be published in Spain in spring 2018 by La Fuga, a small and independent Barcelona-based publishing house founded 
in 2014 that focuses on modern and contemporary foreign fiction, specifically on retrieving books that have gone out of print or still remained unpublished. The latter is the case of Reed's novels: Mumbo Jumbo (2016), Vuelo a Canadá (2018), and La caída de Yellow Back Radio (2020). The three of them have been rendered into Spanish by Inga Pellisa, a prolific young translator whose work on Flight to Canada did not receive much critical attention, since it was only reviewed in small and independent online media, like Indienauta. This website praised her work as well as the novel's soundness, which "remains intact even today, over forty years after the book's publication"4 (Jiménez n.p.).

Flight to Canada is narrated by Raven Quickskill, an educated slave who is soon replaced by an omniscient narrator that speaks Standard English. Nevertheless, the interventions of several black characters from the Swille plantation, such as Uncle Robin, Mammy Barracuda, and 40s, are marked by the features of AfricanAmerican Vernacular English discussed in subsection 3.1. When rendering literary dialect, Pellisa chooses the strategy of dialect compilation because she retains the source names and setting and recreates linguistic variety by playing with the target register and adding colloquial expressions. She also opts for with pseudodialectal translation when she translates literary dialect into a fictional one that is generally accessible for target readers and comprises several traits of substandard Spanish. Table 1 below contains two excerpts from Reed's novel and their corresponding translations to illustrate Pellisa's strategies.

\begin{tabular}{|c|c|}
\hline Reed 77 & Pellisa 97 \\
\hline $\begin{array}{l}\text { "They right. Immigrants comin } \\
\text { over here. Raggedy Micks, Dagos } \\
\text { and things. Jews. The Pope is } \\
\text { behind it. The Pope finance Ellis } \\
\text { Island. That's why it's an island. } \\
\text { Have you ever noticed the Catholic } \\
\text { thing about islands? The Pope and } \\
\text { them be in them places plottin. } \\
\text { They gettin ready to kill Lincoln } \\
\text { so's they can rule America." }\end{array}$ & $\begin{array}{l}\text { - Tienen razón. Los inmigrantes vienen } \\
\text { hacia aquí. Panochos desarrapados, } \\
\text { macarronis y esas cosas. Judíos. El } \\
\text { Papa está detrás. El Papa está } \\
\text { financiando Ellis Island. Por eso es una } \\
\text { isla. ¿Te has dado cuenta del rollo que } \\
\text { se traen los Católicos con las islas? El } \\
\text { Papa y esa gente están ahí conspirando. } \\
\text { Se están preparando para asesinar a } \\
\text { Lincoln y gobernar América. }\end{array}$ \\
\hline
\end{tabular}

\footnotetext{
${ }^{4}$ This translation from Spanish into English has been carried out by the writer of this paper.
} 


\begin{tabular}{|c|c|}
\hline Reed 110 & Pellisa 135 \\
\hline $\begin{array}{l}\text { "Barracuda, what on earth's the } \\
\text { matter? I'm having my 'Siesta.' I } \\
\text {.." } \\
\text { "Your 'Siesta' gon have to wait. It's } \\
\text { your wife again, Arthur. She looks } \\
\text { real Emancipated. Dark circles under } \\
\text { the eyes. Peek'd. She say she not } \\
\text { going to talk unless she fed } \\
\text { intravenous. She say she on strike. } \\
\text { All she do now is lay in bed, watch } \\
\text { television, read movie books and eat } \\
\text { candy. She drinks an awful lot, too, } \\
\text { Mr. Swille. She be listening to that } \\
\text { Beecher Hour show." }\end{array}$ & $\begin{array}{l}\text { - Barracuda, ¿pero qué demonios } \\
\text { ocurre? Estoy en mitad de mi } \\
\text { «Siesta». Yo... } \\
\text { —Tu «Siesta» esa va a tener que } \\
\text { esperar. Es la señá otra vez, Arthur. } \\
\text { Se la ve muy demacratizá. Tié ojeras. } \\
\text { Está toa paliducha. Dice que como no } \\
\text { la den de comer por vía intravenosa } \\
\text { ella no vuelve a hablar. Que está en } \\
\text { huelga. Está tol día na más que tirá } \\
\text { en la cama, viendo la televisión, } \\
\text { leyendo libros de pinículas y } \\
\text { comiendo caramelos. Y también bebe } \\
\text { una barbaridá, señor Swille. Ahora } \\
\text { está escuchando La tarde con } \\
\text { Beecher. }\end{array}$ \\
\hline
\end{tabular}

Table 1. Translating Black English in Flight to Canada

The first fragment above is taken from a conversation between Raven and his friend 40s, another slave who has become paranoid since they escaped from the Camelot plantation. His intervention displays several morpho-syntactic traits of African-American Vernacular English, like the use of the pronoun 'them' as a demonstrative, the lack of auxiliary verbs ('immigrants comin'), the omission of the verb copula ('they right'), marked verb conjugation ('the Pope finance'), and the use of invariant be to make a prediction ('the Pope and them be'); as well as one phonological feature in his pronunciation of verb gerunds as /n/ ('comin', 'plottin', 'gettin'). 40s' speech is marked in the target text not by non-standard spelling or by recreating a particular dialect. Instead, his register has been lowered by including vulgar and derogative terms like rollo, panochos and macarronis, so the translation strategy would be dialect compilation; though it remains unclear why 'micks', a slang term referring to Irish people, has been rendered as panocho, which in Spain alludes colloquially to someone from Murcia. ${ }^{5}$ The second passage shown in Table 1 may be even more revealing in terms of Pellisa's strategy for dealing with Black English in Flight to Canada. In it, Arthur Swille is woken up by Mammy Barracuda, who tells him Ms. Swille is doing odd things for a Southern belle. When describing her habits, the slave woman uses invariant be, omits the third-person singular $-s$ in the present tense, and drops auxiliary verbs and copulas. Pellisa's translation does not use a given Spanish regional dialect. She

\footnotetext{
${ }^{5}$ For more details on this term, refer to the Spanish dictionary at https://dle.rae.es/?w=panocho
} 
recreates literary dialect as a fictional one that may be accessible for target readers, one that mixes diverse traits of colloquial and substandard Spanish, so her strategy is pseudodialectal translation. Thus, Mammy Barracuda's lines display short forms like toa, tol, and na for toda, todo el, and nada, intervocalic $d$ is omitted in past participles such as democratizá and tirá, she uses laísmo in "no la den de comer", and there are a few uneducated mispronunciations illustrated by misspellings like señá and pinículas.

Moreover, Flight to Canada displays nouns and adjectives that refer to slaves' skin color and mixed race, as described in 3.2. They are 'negro', 'quadroon', 'blacks', 'darkies', and 'colored', which have been translated as negro (Pellisa 15), cuarterona (16), negros (27), the diminutive morenitos (121), and the prepositional phrase de color (179), respectively. There is the exception of 'nigger', which, as the first example below illustrates, Pellisa renders as negrata. ${ }^{6}$ This contemporary and pejorative Spanish term may have been introduced due to the temporal distance - over forty years - that separates source and target texts. The second fragment underneath shows that 'yellow' is simply adapted to mulato and not expanded to explain that it means an African-American slave who has a light skin tone. Interestingly, the term 'pickaninny' refers to black children at Camelot and is translated as the less offensive negrito (Pellisa 137-38). Reed's novel introduces innovative and defamatory adjectives for slaves, such as 'coons' and 'kinks', which Pellisa recreates as negros and the derogative monos, the latter comparing them to animals.

\begin{tabular}{|l|l|}
\hline Reed 79 & Pellisa 99 \\
\hline $\begin{array}{l}\text { Cause them niggers don't wont } \\
\text { [sic] no organization. }\end{array}$ & Porque los negratas no necesitan eso. \\
\hline Reed 4 & Pellisa 16 \\
\hline $\begin{array}{l}\text { By now I s'pose that Yellow Judas } \\
\text { Cato done tole you. }\end{array}$ & $\begin{array}{l}\text { Pero supongo que a estas alturas ya } \\
\text { sabrá por } \text { ese Judas Mulato de Cato. }\end{array}$ \\
\hline Reed 27 & Pellisa 43 \\
\hline We treat the Canadians like coons. & $\begin{array}{l}\text { A los canadienses los tratamos como a } \\
\text { negros. }\end{array}$ \\
\hline Reed 52 & Pellisa 71 \\
\hline “Which kink wrote it, Cato?” & $\begin{array}{c}\text { ¿Cuál de esos monos lo ha escrito, } \\
\text { Cato? }\end{array}$ \\
\hline
\end{tabular}

Table 2. The lexicon of skin color in Flight to Canada

\footnotetext{
${ }^{6}$ The Spanish use of negrata may be quite recent. A search in CREA (Corpus de Referencia del Español Actual) dates the first written use of negrata in written texts in Spain back to 2003. This corpus may be accessed online at http://corpus.rae.es/creanet.html
} 
The semantic field of Southern plantations is present in Reed's novel, too. 'Massa', an eye-dialect variant of 'master', is translated as amo (Pellisa17; 35); while the terms referring to the authorities who control slaves, like 'slave catchers', 'bloodhound', and 'overseer', respectively turn into cazadores de esclavos (Pellisa 15), perro sabueso (26), and capataz (204) in La Fuga's target text. It is worth noticing, though, that there are allusions to cultural elements pertaining to this semantic field that have been expanded in the Spanish text, as in the case of the $\mathrm{Ku}$ Klux Klan in the first passage below, just referred to as "the Klan" in the original text; yet others are left in English and no explanation is provided, not even in a footnote, as it happens with the references to the blackface minstrel shows, which emerged in the 1830s and were performed by white men in black-painted faces mocking African-Americans.

\begin{tabular}{|l|l|}
\hline Reed 160 & Pellisa 190 \\
\hline $\begin{array}{l}\text { "Man, they got a group up here } \\
\text { called the Western Guard, make the } \\
\text { Klan look like statesmen. }\end{array}$ & $\begin{array}{l}\text {-Tío, tienen aquí una panda que se } \\
\text { llama la Guardia Occidental que hace } \\
\text { que los del Ku Klux Klan parezcan } \\
\text { dignatarios. }\end{array}$ \\
\hline Reed 9 & Pellisa 21 \\
\hline $\begin{array}{l}\text { Guede is in New Orleans. Guede } \\
\text { got people to write parodies and } \\
\text { minstel shows about Harriet. }\end{array}$ & $\begin{array}{l}\text { Guédé está en Nueva Orleans. Guédé } \\
\text { hizo que se escribieran parodias y } \\
\text { minstrels sobre Harriet. }\end{array}$ \\
\hline
\end{tabular}

Table 3. The lexicon of slavery in Flight to Canada

In Reed's novel, quite a few black slaves have loaded names. They are actually named after animals that represent their defining traits. For example, Raven wants to fly away to Canada like a bird, Mammy Barracuda is as violent as the predator fish to which her name alludes, Uncle Robin seems as shy as a little bird - though he is secretly tampering with his master's last will-, and Stray Leechfield is a cheeky and egotistical slave who takes advantage of the protagonist and tries to make money just for himself, so the name of a parasite worm fits him well. Raven's friend's name, $40 \mathrm{~s}$, could be an allusion to the forty acres and a mule that freed slaves were promised after the Civil War. However, all of these meaningful names are left untranslated and unexplained in Pellisa's version. There are no expansions or footnotes that may help readers guess their meaning. Unless readers are familiar with English and the history of slavery in the United States, these allusions will be lost in the Spanish translation. 


\section{Kindred, by Octavia E. Butler}

Kindred is the story of Dana Franklin, a young black woman who lives with her white husband in Los Angeles. On the eve of July 4th 1976, a strange portal appears out of thin air and she is drawn back in time to the Weylin plantation in Maryland in 1811. Dana meets Rufus — a white boy—and Alice — a black slave girl - and finds out that they are her ancestors. The protagonist travels back in time several times and has to make sure Alice and Rufus survive in the 1800s and have children, because her own existence depends on it. Dana explores the plantation and meets the slaves: Nigel, Luke, Carrie, and Aunt Sarah, the cook who takes care of all the blacks at the Weylin farm. In the 1830s, Rufus and Alice have Hagar, who is Dana's great-great-grandmother. Dana is despaired by Rufus's violent behavior, kills him, loses an arm, and returns to 1976 to heal from her many injuries.

Octavia E. Butler published Kindred in 1979 and, since then, several novels have followed its pattern and blended fantasy with a realistic portrayal of live under slavery-like the haunting spirit in Toni Morrison's Beloved or the subway network in Whitehead's The Underground Railroad - as a way of questioning "previous discourses about slavery while also creating a realistic and feasible alternative to them" (Ryan 130). Aside from time travel, Butler's book is "consistently realistic in presentation and depends on the author's reading of authentic slave narratives and her visits to the Talbot County, Maryland, sites of the novel" (Crossley xii), where Butler traveled in order to come to terms with her ancestors and her own identity. By taking the narrator and protagonist, a contemporary black woman from California, to a plantation in the antebellum South, Butler manages to blend slave narratives with a touch of science fiction and explores "how the imprint of slavery is carried not only in the mind but also on the bodies of all African Americans" (Gates and McKay 2480). This is physically symbolized by Dana losing an arm after killing Rufus in her last trip to the past. In other words, the loss of an arm becomes a memento of the presence of slavery in her family's past. Additionally, it is no coincidence that Dana eventually returns home on July 4th 1976, exactly on the United States' Bicentennial. Her trip to the South makes her reflect on American history and, after killing her sadistic white ancestor, losing an arm, and coming back to her time, Dana frees herself and returns "with a truer understanding of black history in America than the sanitized version in the popular media had ever given her" (Crossley xix).

Similarly to Flight to Canada, Kindred waited for nearly forty years to be published in Spanish by Capitán Swing, an independent Madrid-based publishing house that specializes in books about contemporary societies and cultures. This company has shown interest in African-American history and has edited the Spanish versions of Malcolm X's and Angela Davis's respective autobiographies, 
as well as the latest edition of Styron's The Confessions of Nat Turner. In spring 2018, Capitán Swing published Kindred. It was titled Parentesco and rendered into Spanish by Amelia Pérez de Villar, who is also a novelist. At the book presentation held at La Casa del Lector on April 28th 2018, she explained that translating Butler's novel had been a joy (Pérez de Villar, Ciclo charla n.p.). She commented she had read books on slavery to understand the historical references in Kindred and she clarified she had not resorted to a specific target variety to recreate literary dialect. Instead, the translator claimed she had tried to use a few quotation marks and italics in order to mark the speech of certain characters. Her work was reviewed in small and online newspapers, which compared Kindred's blend of fantasy and history to Morrison's Beloved and lamented that Spanish readers had to wait for nearly four decades to read the novel that established Butler as a major science fiction writer (Hidalgo n.p.).

As can be observed in Table 4 below, Pérez de Villar plays with several strategies to introduce linguistic variety in the target text. In the first fragment, Dana talks to Aunt Sarah, whose lines feature marked verb conjugation and omit auxiliary verbs, in contrast with the protagonist's Standard English. The translator resorts to compensation and to dialect compilation to differentiate the slave's lines from Dana's. Thanks to these strategies, Aunt Sarah's lines include the vulgar form 'el señor Kevin ese', postponing the demonstrative to the proper noun and lowering this character's speech in the target text. This mark compensates Aunt Sarah's use of Black English in a line that was originally unmarked in the source text. Besides, when Dana talks to Nigel-Sarah's son-in the second fragment, he omits the verb 'are' in "you s'pose". Pérez de Villar compensates this mark by recreating a fictional target dialect when the slave misarticulates tienes as tiés, a substandard form that is italicized in Parentesco. It is a bit strange, though, that Nigel mispronounces tienes but then he does not omit the intervocalic $d$ in cuidado, saying cuidao, as it happened with Mammy Barracuda in Vuelo a Canadá. Lastly, in the third excerpt from Table 4, Sarah tells the protagonist about the fate of Isaac, who had to run away after beating Rufus. The slave woman drops the unstressed vowel in 'about', pronounces it as 'bout', and then deletes the initial syllable in 'before'. Parentesco compensates this with the short form tó for todo and with the vulgar mispronunciation a'nde for adonde. Both substandard forms are italicized and illustrate Pérez de Villar's use of pseudodialectal translation to recreate Black English in the target text. In other words, she marks the characters' speech as uneducated but does not match their lines to a specific geographical variety. Nevertheless, it needs to be pointed out that the inclusion of the contemporary and informal adverb síp may be puzzling for readers, even though it tries to reproduce the English 'yeah'. 


\begin{tabular}{|c|c|}
\hline & $3-84$ \\
\hline $\begin{array}{l}\text { "Your husband... was that Mister } \\
\text { Kevin?" } \\
\text { "Yes." } \\
\text { "Nigel said you and him was } \\
\text { married. I didn't believe it." } \\
\text { "We kept quiet about it because it's } \\
\text { not legal here." } \\
\text { "Legal!" Another sound of disgust. } \\
\text { "I guess what Marse Rufe done to } \\
\text { that girl is legal." } \\
\text { I shrugged. }\end{array}$ & $\begin{array}{l}\text { — ¿Tu marido... es el señor Kevin } \\
\text { ese? } \\
\text { —Sí. } \\
\text { —Dijo Nigel que estabais casados, } \\
\text { pero yo no me lo creí. } \\
\text { —No dijimos nada porque aquí es } \\
\text { ilegal. } \\
\text { — ¡Ilegal! — Otro chasquido de } \\
\text { disgusto_. Y seguramente lo que ha } \\
\text { hecho el señorito Rufe a esa muchacha } \\
\text { es legal. } \\
\text { Me encogí de hombros. }\end{array}$ \\
\hline Butle & 'érez \\
\hline $\begin{array}{l}\text { n and you better take care } \\
\text { you better do a good job. } \\
\text { h says you call her if you } \\
\text { "' } \\
\text { Thank her for me." }\end{array}$ & $\begin{array}{l}\text { —El amo dice que tiés que tener } \\
\text { cuidado de él y que más te vale } \\
\text { hacerlo bien. Y tía Sarah, que la llames } \\
\text { si necesitas ayuda. } \\
\text { — Gracias. Y dáselas de mi parte. }\end{array}$ \\
\hline Butle & 83 \\
\hline $\begin{array}{l}\text { "They cut off the boy's ears." } \\
\text { I jumped. "Isaac?" } \\
\text { "Yeah. Cut them both off. He } \\
\text { fought. Strong boy, even if he didn't } \\
\text { show much sense. The judge's son } \\
\text { hit him, and he struck back. And he } \\
\text { said some things he shouldn't have } \\
\text { said." } \\
\text { "Rufus said they sold him to a } \\
\text { Mississippi trader." } \\
\text { "Did. After they got through with } \\
\text { him. Nigel told me 'bout it--how } \\
\text { they cut him, beat him. He'll have } \\
\text { to do some healing 'fore he can go } \\
\text { to Mississippi or anywhere else." }\end{array}$ & $\begin{array}{l}\text { —Le cortaron las orejas. } \\
\text { Di un respingo. } \\
\text { —AA Isaac? } \\
\text { —Síp. Las dos. Se resistió. Es un chico } \\
\text { fuerte, aunque a veces no parece que } \\
\text { tenga mucha sesera. El hijo del juez le } \\
\text { pegó y él le devolvió los golpes. Y dijo } \\
\text { cosas que no tenía que haber dicho. } \\
\text { —Me ha dicho Rufus que lo habían } \\
\text { vendido a un negrero de Misisipi. } \\
\text { —Eso, sí. Cuando acabaron con él. } \\
\text { Nigel me lo contó tó: cómo le } \\
\text { cortaron, le pegaron... Tendrá que } \\
\text { curarse un poco antes de ir a Misisipi o } \\
\text { a'nde sea. }\end{array}$ \\
\hline
\end{tabular}

\section{Table 4. Translating Black English in Kindred}

Regarding lexical elements, the problematic translation of the derogatory adjective 'nigger' comes up again. In one of Dana's first trips to the past, Rufus calls her 'a 
nigger'. The protagonist is shocked at hearing such an offensive word and tells the young boy she is a black woman. She gives Rufus three alternatives: 'black', 'Negro', and 'colored'. The translation of these adjectives related to race may be quite troublesome for the Spanish version, as there is no term as pejorative and loaded with references to the history of American slavery as 'nigger' in English. A possible derogatory option would be negrata, yet it is too contemporary, as discussed in the previous section on Flight to Canada. Nevertheless, the fragment in Table 5 illustrates how Pérez de Villar's solution has been to expand the terms related to skin color, so that 'niggers', 'black', 'Negro', and 'colored' become negros, personas negras, de raza negra, and de color, respectively. Unfortunately, Kindred does not hold any instances of other nouns and adjectives pertaining to the semantic field of skin color, like quadroon, pickaninny, or high-yellow slaves.

\begin{tabular}{|l|l|}
\hline Butler 60-61 & Pérez de Villar 75-76 \\
\hline "The boy learned to talk that & -El chico ha aprendido a hablar así por su \\
way from his mother," I said & madre - dije suavemente-. Y por su \\
softly. "And from his father, & padre, y probablemente por los propios \\
and probably from the slaves & esclavos. \\
themselves." & ¿He aprendido a hablar cómo? - \\
"Learned to talk what way?" & preguntó Rufus. \\
asked Rufus. & -Como hablas de los negros —respondí \\
"About niggers," I said. "I don’t & yo-. No me gusta esa palabra, ¿recuerdas \\
like that word, remember? Try & que te lo dije? Intenta no decirlo con \\
calling me black or Negro or & desprecio. Puedes decir personas negras, \\
even colored." & de raza negra o de color. \\
\hline
\end{tabular}

Table 5. The lexicon of skin color in Kindred

Kindred encloses several references to the semantic field of Southern plantations. These have been translated into Spanish without expanding them or adding footnotes to comment on historical and cultural allusions, so that a 'slave market' becomes mercado de esclavos (Pérez de Villar 65), the 'overseer' is rendered as capataz (83), 'marse' is recreated with the diminutive señorito (162), and a 'slave trader' is translated, quite appropriately, as negrero (109), that is, a person who makes business selling black slaves. It is interesting to notice, too, how the narrator reflects on the meaning of some cultural elements she sees during her journeys into the past because she has read about them in history books. That is the case of 'slave patrols' and the tradition of 'jumping the broom' to get married. Her thoughts on what these mean work as expansions that help target readers get familiar with the semantic field of Southern plantations, as the next passages in Table 6 illustrate. 


\begin{tabular}{|c|c|}
\hline Butl & Pérez de Villar 46-47 \\
\hline $\begin{array}{l}\text { Patrols. Groups of young whites } \\
\text { who ostensibly maintained order } \\
\text { among the slaves. Patrols. } \\
\text { Forerunners of the Ku Klux Klan. } \\
\text { The man's screaming stopped. After } \\
\text { a moment, I looked up and saw the } \\
\text { patrollers were untying him. }\end{array}$ & $\begin{array}{l}\text { Patrullas. Grupos de jóvenes blancos } \\
\text { que mantenían el orden entre los } \\
\text { esclavos. Patrullas. Los antecesores } \\
\text { del Ku Klux Klan. } \\
\text { El hombre dejó de gritar. Al cabo de } \\
\text { un momento levanté la vista y vi que } \\
\text { los patrulleros le estaban desatando. }\end{array}$ \\
\hline & e villa \\
\hline $\begin{array}{l}\text { "Marse Rufe paid a free preacher } \\
\text { from town to come and say the same } \\
\text { words they say for white folks and } \\
\text { free niggers. Didn't have to jump no } \\
\text { broomstick." } \\
\text { I nodded, remembering what I'd } \\
\text { read about the slaves' marriage } \\
\text { ceremonies. They jumped } \\
\text { broomsticks, sometimes backward, } \\
\text { sometimes forward, depending on } \\
\text { local custom. }\end{array}$ & $\begin{array}{l}\text { - El señorito Rufe pagó a un } \\
\text { predicador para que viniera del pueblo } \\
\text { y dijera esas palabras que dicen para } \\
\text { casar a los blancos y a los negros } \\
\text { libres. Así no tuvimos que saltar el } \\
\text { palo de la escoba. } \\
\text { Asentí, recordando lo que había leído } \\
\text { sobre las ceremonias de boda de los } \\
\text { esclavos. Tenían que saltar el palo de } \\
\text { una escoba, a veces hacia atrás y otras } \\
\text { hacia delante, según las costumbres } \\
\text { locales. }\end{array}$ \\
\hline
\end{tabular}

Table 6. The lexicon of slavery in Kindred

Lastly, black slaves in Kindred do not have loaded names, but conventional and biblical ones such as Sarah, Alice, Isaac, Nigel, Luke, and Hagar. These proper nouns remain untranslated and have not been adapted to Spanish spelling in Pérez de Villar's version. Despite the intertextual power of these allusions to the Bible, the names are left in English in Parentesco.

\section{Concluding Remarks}

In Vuelo a Canadá, dialect compilation and pseudodialectal translation are combined when Pellisa keeps the source setting and recreates Black English as a literary dialect that includes colloquial expressions (rollo, macarronis) and contains substandard short forms (toa, tol, na), laísmo, mispronunciations (pinículas), and the omission of intervocalic $d$ in past participles (tirá). Analogously, Pérez de Villar uses dialect compilation, pseudodialectal translation, and compensation to deal with African-American Vernacular English in Parentesco, contrasting it with Dana's Standard English. Thus, when slaves like Aunt Sarah and Nigel talk to the protagonist, Pérez de Villar adds italics and 
lowers their register as these characters postpone the demonstrative to proper nouns, utter mispronunciations (tiés, a'nde), and use short forms (tó).

By playing with these three strategies, Pellisa and Pérez de Villar produce marked target texts that transform Black English not into a specific regional variety from the recipient culture, but into a non-standard one that plays with a set of features borrowed from colloquial and spoken Spanish. Therefore, the two translators manage to reflect the alterity introduced by the portrayal of AfricanAmerican Vernacular English in the source novels. Slaves speak substandard Spanish in Vuelo a Canadá and Parentesco, so their literary dialect tells them apart from white masters - like Arthur Swille and Rufus Weylin - and from educated black characters - Dana-, who speak the standard variety. Consequently, slaves can be differentiated from their white oppressors not only by the progression of the novels' plot and the distinct roles they play, but also by their particular use of non-standard language, which retells and supports the narrative Us vs. the Other that was present in Reed's and Butler's subversive texts.

Nonetheless, it should be highlighted that Pellisa's and Pérez de Villar's versions were both published by small and independently-run companies-La Fuga and Capitán Swing, respectively - that strive to bring contemporary texts to Spanish readers. Given their small and distinct readerships, these publishing companies can allow room for such literary games, play with spelling and literary dialects. Future studies could analyze the different translation strategies favored by multinational groups like Penguin Random House and check if they opt for recreating or suppressing linguistic variety in neo-slave narratives aimed at their broader readership; for instance, the aforementioned The Underground Railroad, which was translated into Spanish by Cruz Rodríguez Juiz in 2017.

With respect to lexical elements, Table 7 gives a global vision of translators' choices. There seems to be an agreement in rendering 'Negro' as negro and 'colored' as the prepositional phrase de color. The term 'nigger', as advanced above, has proven to be troublesome, because it is complicated to convey in Spanish the historical and offensive load it has in the American context. Pérez de Villar simplifies it as negro, yet Pellisa offers the alternative of rendering it as the derogative negrata, a rather contemporary term that may only work in an anachronistic and humorous novel such as Reed's, but not in other slave narratives. Moving on to the semantic field of Southern plantations, it looks like both translators agree on transforming 'overseer' into capataz and on not adding any footnotes or expansions to comment on historical allusions. Interestingly, they choose a diminutive for the Spanish version of 'massa' and 'marse', the eyedialect variants of 'master'. 


\begin{tabular}{|c|c|c|c|c|c|c|c|c|}
\cline { 2 - 8 } \multicolumn{1}{c|}{} & Negro & Nigger & Colored & Darky & Pickaninny & $\begin{array}{c}\text { Massa, } \\
\text { Marse }\end{array}$ & Overseer & Patrollers \\
\hline$K t C$ & negro & negrata & $\begin{array}{c}\text { de } \\
\text { color }\end{array}$ & morenito & negrito & amito & capataz & $\varnothing$ \\
\hline$K$ & $\begin{array}{c}\text { de raza } \\
\text { negra }\end{array}$ & negro & $\begin{array}{c}\text { de } \\
\text { color }\end{array}$ & $\varnothing$ & $\varnothing$ & señorito & capataz & patrulleros \\
\hline
\end{tabular}

Table 7. Translation of lexical elements in Flight to Canada $(\mathrm{FtC})$ and Kindred $(K)$

Lastly, the two translators concur on leaving proper nouns untranslated in the target text. It does not matter if slaves have conventional biblical names, like Sarah and Hagar in Kindred, or meaningful ones that allude to animals representing the characters' defining traits, as Raven Quickskill, Leechfield and Mammy Barracuda in Flight to Canada. Pellisa and Pérez de Villar have opted for not adapting them to Spanish spelling, leaving names untranslated and unexplained in the target texts.

When analyzing this type of translation, there are several difficulties that researchers need to consider. In addition to the complexities of African-American neo-slave narratives described above, such as the use of Black English, the diverse lexicon of slavery, and meaningful proper nouns, there are two agents that influence the translation of novels into Spanish and that could be observed in future studies. As hinted before, patrons play a significant role in the selection of which slave narratives are to be translated and what kind of strategies are deemed acceptable for the target readers. It would be revealing to check if bigger publishing houses opt for an alternative when rendering the voice of the dispossessed slaves into Spanish, for instance in Debolsillo's version of Toni Morrison's Beloved (which was published in 2001 and reprinted a translation from 1988) and in Salamandra's translation of Yaa Gyasi's Homegoing (2017). The second agent that may be taken into account is censors and how they condition the Spanish translation of neo-slave narratives, because the early novels of this genre underwent state censorship. This is the case of Margaret Walker's Jubilee, whose Spanish version was published by Plaza y Janés in 1968. Interestingly, in 2016 Capitán Swing released another narrative, Las confesiones de Nat Turner, and reprinted a previously censored translation, the one carried out by Andrés Bosch in 1968 and first published by Lumen. It would be interesting to observe, in future papers, how censors and patrons affect the translation and reception of neo-slave narratives, studying if other rendered novels follow or deviate from the strategies discussed here in the analysis of the Spanish versions of Flight to Canada and Kindred. 


\section{WORKS CITED}

Baker, Mona. Translation and Conflict: A Narrative Account. London: Routledge, 2006. DOI: https://doi.org/10.4324/9780203099919

Bell, Bernard W. The Afro-American Novel and Its Tradition. Amherst: University of Massachusetts Press, 1987.

Butler, Octavia E. Kindred. Boston: Beacon Press, 1988.

Charyn, Jerome. "Flight to Canada Review". The New York Times (19 Sept. 1976). Web. $\quad 5 \quad$ May 2019. <https://www.nytimes.com/1976/09/19/archives/flight-to-canadacanada.html>.

Crossley, Robert. "Introduction to Kindred". Kindred. By Octavia E. Butler. Boston: Beacon Press, 1988. ix-xxvii.

Depardieu, Benoît. "Her/His-(s)Tory: Confronting the 'Shackles' of the AfricanAmerican Urtext: Walker, Gaines, Reed Re-Write the Slave Narrative". Revisiting Slave Narratives I: Les Avatars Contemporains Des Récits d'esclaves. Ed. Judith Misrahi-Barak. Montpellier: Presses Universitaires de la Méditerranée, 2016. 123-48.

Dubey, Madhu. "Neo-Slave Narratives". A Companion to African American Literature. Ed. Gene Andrew Jarrett. Oxford: Wiley-Blackwell, 2010. 332-46. DOI: https://doi.org/10.1002/9781444323474.ch22

Gates, Henry Louis, Jr. and Nellie Y. McKay. Eds. The Norton Anthology of African American Literature. New York: Norton, 1997.

Gould, Philip. "The Rise, Development, and Circulation of the Slave Narrative". The Cambridge Companion to the African American Slave Narrative. Ed. Audrey A. Fisch. Cambridge: Cambridge University Press, 2007. 11-27. DOI: https://doi.org/10.1017/CCOL0521850193.002

Green, Lisa J. African American English: A Linguistic Introduction. Cambridge: Cambridge University Press, 2002. DOI: https://doi.org/10.1017/CBO9780511800306

Hidalgo, Arrate. "Parentesco: La mirada al pasado de la gran dama de la ciencia ficción”. El Salto (28 Apr. 2018). Web. 11 Sept. 2019. $<$ https://www.elsaltodiario.com/literatura/parentesco-la-mirada-alpasado-de-la-gran-dama-de-la-ciencia-ficcion>.

Jiménez, Raúl. “Vuelo a Canadá, de Ishmael Reed”. Indienauta (2 May 2018). Web. 23 May 2019. <https://www.indienauta.com/libros/vuelo-canadaishmael-reed-la-fuga-2018/>. 
Manini, Luca. "Meaningful Literary Names: Their Forms and Functions, and Their Translation". The Translator 2.2 (1996): 161-78. DOI: https://doi.org/10.1080/13556509.1996.10798972

McWhorter, John. "The Idea That Whites Can't Refer to the N-Word". The Atlantic (27 Aug. 2019). Web. 16 June 2020. <https://www.theatlantic.com/ideas/archive/2019/08/whites-refer-tothe-n-word/596872/>.

Minnick, Lisa. Dialect and Dichotomy: Literary Representations of African American Speech. Tuscaloosa: The University of Alabama Press, 2004.

Mufwene, Salikoko S. "African-American English”. The Cambridge History of the English Language. English in North America. Ed. John Algeo. Cambridge: Cambridge University Press, 2001. 291-324. DOI: https://doi.org/10.1017/CHOL9780521264792.009

O’Neale, Sondra A. “Ishmael Reed's Fitful Flight to Canada: Liberation for Some, Good Reading for All". Callaloo 4 (1978): 174-77. DOI: https://doi.org/10.2307/2930908

Pellisa, Inga, translator. Vuelo a Canadá. By Ishmael Reed. Barcelona: La Fuga, 2018.

Pérez de Villar, Amelia, translator. Parentesco. By Octavia E. Butler. Madrid: Capitán Swing, 2018.

---. Ciclo charla entre traductores: Presentación de Parentesco. Casa del Lector, Madrid. 28 April 2018.

Reed, Ishmael. Flight to Canada. New York: Atheneum, 1989.

Rica Peromingo, Juan Pedro, and Jorge Braga Riera. Herramientas y técnicas para la traducción inglés-español: Los textos literarios. Madrid: Escolar y Mayo, 2015.

Rickford, John Russell, and Russell John Rickford. Spoken Soul: The Story of Black English. New York: John Wiley and Sons, 2009.

Rodriguez, Junius P. Ed. Slavery in the United States: A Social, Political, and Historical Encyclopedia. Santa Barbara: ABC-CLIO, 2007.

Rushdy, Ashraf H. A. Neo-Slave Narratives: Studies in the Social Logic of a Literary Form. Oxford: Oxford University Press, 1999.

Ryan, Tim A. Calls and Responses: The American Novel of Slavery since Gone with the Wind. Baton Rouge: Louisiana State University Press, 2008. DOI: https://doi.org/10.2307/27694853 
Smith, Valerie. "Neo-Slave Narratives". The Cambridge Companion to the African American Slave Narrative. Ed. Audrey A. Fisch. Cambridge: Cambridge University Press, 2007. 168-85. DOI: https://doi.org/10.1017/CCOL0521850193.011

Zanger, Jules. "Literary Dialect and Social Change". Midcontinent American Studies Journal 7.2 (1966): 40-48.

Received September 14, 2020 Revised version accepted November 9, 2020 